Wioleta Wasil

\title{
Ocena petycji w sprawie zmiany ustawy - Prawo oświatowe w zakresie preambuły
}

\begin{abstract}
Celem petycji jest podjęcie inicjatywy ustawodawczej w sprawie wykreślenia z preambuły ustawy - Prawo oświatowe frazy: „respektując chrześcijański system wartości”. Realizacja propozycji mieści się w zakresie swobody decyzyjnej ustawodawcy. Jednakże w ocenie autora opinii przytoczona w petycji argumentacja za usunięciem tego zapisu nie jest w pełni przekonująca. Różnorodność treści nauczania obecna w podstawie programowej nie jest wyrazem pogwałcenia czy braku respektowania wartości, do których odwołuje się preambuła. Przeciwnie, pozwala ona spełnić podstawowy cel szkoły, jakim jest troska o wszechstronny rozwój każdego ucznia.
\end{abstract}

Słowa kluczowe: oświata, chrześcijaństwo, petycja

Assessment of petition regarding amendment of the Act - the Education law with respect to the preamble: The aim of the petition is to take a legislative initiative on the deletion from the preamble of the Education Law of the phrase: "respecting the Christian system of values". The implementation of the proposal falls within the scope of the legislator's discretion. However, in the opinion of the author, the argument in favour of removing this provision is not fully convincing. The diversity of teaching content present in the core curriculum is not an expression of violation or lack of respect for the values referred to in the preamble. On the contrary, it meets the primary goal of any school, which is to ensure the comprehensive development of each student.

Keywords: education, christianity, petition

Doktorant na Wydziale Prawa Kanonicznego UKSW, ekspert ds. oceny skutków regulacji BAS

- wioleta.wasil@sejm.gov.pl • https://orcid.org/0000-0002-6286-1055

\section{Treść i cel petycji}

Przedmiotem petycji nr 145-532/18 jest żądanie nowelizacji ustawy z 14 grudnia 2016 r. - Prawo oświatowe (Dz.U. 2018, poz. 996, ze zm.) w zakresie preambuły. Jak podaje Autor petycji, jej celem jest podjęcie inicjatywy ustawodawczej w sparwie wykreślenia z preambuły ustawy - Prawo oświatowe frazy: „respektując chrześcijański system wartości”.

Opinia prawna na temat petycji nr 145-532/19 w sprawie zmiany ustawy $z$ dnia 14 grudnia 2016 r. - Prawo oświatowe (Dz.U. z 2018 r. poz. 996 ze zm.) w zakresie preambuty sporządzona 10 czerwca 2019 r. na zlecenie przewodniczącego Komisji do Spraw Petycji; BAS-WAP 843/19. 


\section{Czy petycja mieści się w zakresie zadań i kompetencji adresata petycji (art. 2 ust. 3 ustawy o petycjach)?}

Petycja dotyczy zmiany ustawy przez Sejm. Zgodnie z art. 95 ust. 1 Konstytucji RP władzę ustawodawczą w Rzeczypospolitej Polskiej sprawują Sejm i Senat. Natomiast stosownie do art. 118 ust. 1 Konstytucji RP inicjatywa ustawodawcza przysługuje m.in. posłom. Artykuł 32 ust. 2 regulaminu Sejmu, w związku z art. 112 Konstytucji RP, precyzuje, że poselskie projekty ustaw mogą być wnoszone przez komisje sejmowe lub grupę co najmniej 15 posłów podpisujących projekt.

Uwzględniając powyższe, należy uznać, że petycja mieści się w zakresie zadań i kompetencji Sejmu.

\section{Wymogi formalne (art. 4 ust. 1 i 2 ustawy o petycjach)}

Petycja spełnia wymogi formalne określone w art. 4 ust. 1 i 2 ustawy o petycjach.

\section{Kwestie, które ekspert uznaje za istotne w związku z petycją}

Autor petycji postuluje o usunięcie z treści preambuły sformułowania „respektując chrześcijański system wartości”. Uznaje on, że przez pominięcie w podstawie programowej biblijnego opisu stworzenia, na rzecz niepopartej dowodami teorii ewolucji, deklarowanie respektowania chrześcijańskiego systemu wartości w nauczaniu i wychowaniu jest zbędne.

Na podstawie art. 15 ust. 1 ustawy z 14 grudnia 2016 r. - Przepisy wprowadzające ustawę - Prawo oświatowe (Dz.U. 2017, poz. 60, ze zm.) uchylono preambułę do ustawy z 7 września 1991 r. o systemie oświaty (t.j. Dz.U. 2018, poz. 1457, ze zm.), którą w niezmienionym brzmieniu zamieszczono w ustawie Prawo oświatowe. Treść preambuły jest następująca: Oświata w Rzeczypospolitej Polskiej stanowi wspólne dobro całego społeczeństwa; kieruje się zasadami zawartymi w Konstytucji Rzeczypospolitej Polskiej, a także wskazaniami zawartymi w Powszechnej Deklaracji Praw Człowieka, Międzynarodowym Pakcie Praw Obywatelskich i Politycznych oraz Konwencji o Prawach Dziecka. Nauczanie i wychowanie - respektując chrześcijański system wartości - za podstawe przyjmuje uniwersalne zasady etyki. Kształcenie i wychowanie służy rozwijaniu u młodzieży poczucia odpowiedzialności, miłości Ojczyzny oraz poszanowania dla polskiego dziedzictwa kulturowego, przy jednoczesnym otwarciu się na wartości kultur Europy i świata. Szkoła winna zapewnić każdemu uczniowi warunki niezbędne do jego rozwoju, przygotować go do wypełniania obowiązków rodzinnych i obywatelskich $w$ oparciu o zasady solidarności, demokracji, tolerancji, sprawiedliwości i wolności. 
Preambuła do ustawy - Prawo oświatowe odwołuje się do systemu wartości, na jakim oparte ma być nauczanie i wychowanie. Ustawodawca $\mathrm{z}$ jednej strony zadeklarował poszanowanie dla chrześcijańskiego systemu wartości, a z drugiej strony wskazał na uniwersalne zasady etyki. W literaturze przedmiotu podaje się, że przez odniesienie do tych wartości: ustawodawca uznaje prawa ludzi wierzacych, wskazując na przynależność naszego kraju do określonego kręu kulturowego, ale jednocześnie szanuje przekonania innych, wskazując, że to jednak uniwersalne zasady etyki sa podstawa systemu nauczania ${ }^{2}$.

W doktrynie podkreśla się, że preambuła do ustawy o systemie oświaty (obecnie ustawy - Prawo oświatowe), choć sama w sobie nie niesie konkretnej treści normatywnej, może być postrzegana jako źródło wytycznych dla wykładni teleologicznej, czyli odwołującej się do celów, do osiągnięcia których ustawodawca ustanowił regulację prawną ${ }^{3}$ Uprawnione jest zatem twierdzenie, że zapis preambuły do ustawy - Prawo oświatowe dotyczący respektowania chrześcijańskiego sytemu wartości w nauczaniu i wychowaniu stanowi istotną wskazówkę interpretacyjną tekstu ustawy. Taką też funkcję pełni w przypadku interpretacji celów kształcenia, przy uwzględnieniu których tworzy się podstawę programową.

Zgodnie z art. 4 ust. 24 ustawy - Prawa oświatowego przez: podstawe programowa wychowania przedszkolnego lub podstawe programowa kształcenia ogólnego - należy rozumieć obowiązkowe zestawy celów kształcenia i treści nauczania, w tym umiejętności, opisane w formie ogólnych i szczegółowych wymagań dotyczących wiedzy i umiejętności, które powinien posiadać uczeń po zakończeniu określonego etapu edukacyjnego, oraz zadania wychowawczo-profilaktyczne szkoły, uwzględniane odpowiednio w programach wychowania przedszkolnego, programach nauczania i podczas realizacji zajęć z wychowawca oraz umożliwiające ustalenie kryteriów ocen szkolnych i wymagań egzaminacyjnych, a także warunki i sposób realizacji tych podstaw programowych. Na mocy art. 47 ust. 1 ustawy Prawo oświatowe:

1. Minister właściwy do spraw oświaty $i$ wychowania określi, $w$ drodze rozporzadzenia:

1) podstawe programowa:

a) wychowania przedszkolnego,

b) kształcenia ogólnego dla szkoły podstawowej, w tym dla uczniów z niepełnosprawnościa intelektualna $w$ stopniu umiarkowanym lub znacznym,

2 A. Król, P. Kuzior, M. Łyszczarz, Prawo oświatowe. Komentarz do ustawy o systemie oświaty, Warszawa-Bielsko-Biała 2011, s. 16.

3 M. Pilich, Ustawa o systemie oświaty. Komentarz, 2015, LEX; L. Morawski, Zasady wykładni prawa, Toruń 2010, s. 159. Taki charakter przypisuje się również preambułom do aktów normatywnych w orzecznictwie Trybunału Konstytucyjnego (zob. wyroki: z 11 maja 2005 r., sygn. akt K 18/04, a także z 11 maja 2007 r., sygn. akt K 2/07) oraz Sądu Najwyższego (zob. uchwała z 8 stycznia 1982 r., sygn. akt III CZP 58/81; wyrok z 29 marca 2000 r., sygn. akt III RN 137/99). 
c) kształcenia ogólnego dla liceum ogólnokształcącego,

d) kształcenia ogólnego dla technikum,

e) kształcenia ogólnego dla branżowej szkoły I stopnia,

f) kształcenia ogólnego dla szkoły specjalnej przysposabiającej do pracy,

g) kształcenia ogólnego dla branżowej szkoły II stopnia,

h) kształcenia ogólnego dla szkoły policealnej

- uwzględniajac w szczególności zestawy celów kształcenia i treści nauczania, umiejętności uczniów, a także zadania wychowawczo-profilaktyczne szkoły, odpowiednio do poszczególnych etapów edukacyjnych i typów szkót.

Tworzenie założeń do podstawy programowej kształcenia ogólnego powierza się ekspertom ${ }^{4}$. W odpowiedzi Ministerstwa Edukacji Narodowej na „Informacje o wynikach kontroli NIK" z 20 maja 2019 r. w sprawie zmian w systemie oświaty nr ewid. 42/2019/P/18/027/KNO stwierdzono, że: Minister Edukacji Narodowej ma prawo do podejmowania autonomicznych decyzji, a w tym konkretnym przypadku [w sprawie wyboru ekspertów - uwaga V.W.] na podstawie rekomendacji. Przepisy prawa oświatowego nie określaja wymagań wobec ekspertów zewnętrznych, którzy na zlecenie Ministra Edukacji Narodowej uczestnicza w pracach nad przygotowaniem projektu podstawy programowej. Biorac pod uwage specyfike dokumentu, jakim jest podstawa programowa, przy wyborze ekspertów brane sa pod uwage osoby reprezentujące wysoki poziom merytoryczny $w$ zakresie dyscypliny wiedzy, która stanowi bazę danego przedmiotu, jak również bardzo dobrze znające praktykę szkolna lub egzaminacyjna. W zespołach ekspertów sa zatem zawsze nauczyciele akademiccy, doświadczeni nauczyciele poszczególnych typów szkót, metodycy i eksperci systemu egzaminacyjnego ${ }^{5}$.

Szkoły zobowiązane są do realizacji podstaw programowych i ramowych planów nauczania, co zgodnie z art. 55 ust. 2 pkt 2 ustawy - Prawo oświatowe podlega nadzorowi pedagogicznemu. Zgodnie z rozporządzeniem Ministra Edukacji Narodowej z 27 sierpnia 2012 r. w sprawie podstawy programowej wychowania przedszkolnego oraz kształcenia ogólnego w poszczególnych typach szkół (Dz.U. poz. 977, ze zm.; dalej: rozporządzenie w sprawie podstawy programowej dla szkół podstawowych) oraz rozporządzeniem Ministra Edukacji Narodowej z 30 stycznia 2018 r. w sprawie podstawy programowej kształcenia ogólnego dla liceum ogólnokształcącego, technikum oraz branżowej szkoły II stopnia w szkołach (Dz.U. poz. 467; dalej: rozporządzenie w sprawie podstawy programowej dla szkół ponadpodstawowych) znajomość teorii ewolucji - jako źródła różnorodności biologicznej - uwzględniona jest w celach ogólnych kształcenia biologii w szkołach podstawowych i ponadpodstawowych.

4 K. Konarzewski, Reforma oświaty. Podstawa programowa $i$ warunki kształcenia, Warszawa 2004, s. 16, 109.

5 Https://www.gov.pl/web/edukacja/zmiany-w-oswiacie-zostaly-przygotowane-rzetelnie [dostęp 30 maja 2019 r.]. 
Szczegółowe wymagania w stosunku do treści kształcenia w zakresie teorii ewolucji dotyczą:

- w przypadku szkoły podstawowej (zgodnie z załącznikiem nr 4 pkt IX rozporządzenia w sprawie podstawy programowej dla szkół podstawowych):

IX. Ewolucja życia. Uczeń:

1) wyjaśnia istotę procesu ewolucji organizmów i przedstawia źródła wiedzy o jej przebiegu;

2) wyjaśnia na przykładach, na czym polega dobór naturalny i sztuczny oraz przedstawia różnice między nimi;

3) przedstawia podobieństwa i różnice między człowiekiem a małpami człekokształtnymi jako wynik procesów ewolucyjnych.

- w przypadku szkół ponadpodstawowych (zgodnie z załącznikiem nr 1 pkt IX rozporządzenia $\mathrm{w}$ sprawie podstawy programowej dla szkół ponadpodstawowych):

IX. Ewolucja. Uczeń:

1) przedstawia historię myśli ewolucyjnej;

2) przedstawia podstawowe źródła wiedzy o mechanizmach i przebiegu ewolucji;

3) określa pokrewieństwo ewolucyjne gatunków na podstawie analizy drzewa filogenetycznego;

4) przedstawia rodzaje zmienności i wykazuje znaczenie zmienności genetycznej $w$ procesie ewolucji;

5) wyjaśnia mechanizm działania doboru naturalnego i przedstawia jego rodzaje (stabilizujący, kierunkowy i różnicujący);

6) wykazuje, że dzięki doborowi naturalnemu organizmy zyskuja nowe cechy adaptacyjne;

7) określa warunki, w jakich zachodzi dryf genetyczny;

8) przedstawia przyczyny zmian częstości alleli w populacji;

9) wyjaśnia, dlaczego mimo działania doboru naturalnego w populacji ludzkiej utrzymują się allele warunkujące choroby genetyczne;

10) przedstawia gatunek jako izolowana pule genową;

11) przedstawia specjacje jako mechanizm powstawania gatunków;

12) rozpoznaje, na podstawie opisu, schematu, rysunku, konwergencje i dywergencje;

13) przedstawia hipotezy wyjaśniające najważniejsze etapy biogenezy;

14) porzadkuje chronologicznie wydarzenia z historii życia na Ziemi; wykazuje, że zmiany warunków środowiskowych miały wpływ na przebieg ewolucji;

15) porzadkuje chronologicznie formy kopalne człowiekowatych wskazując na ich cechy charakterystyczne;

16) określa pokrewieństwo człowieka z innymi zwierzętami, na podstawie analizy drzewa rodowego; 
17) przedstawia podobieństwa między człowiekiem a innymi naczelnymi; przedstawia cechy odróżniające człowieka od małp człekokształtnych;

18) analizuje różnorodne źródła informacji dotyczace ewolucji człowieka i przedstawia tendencje zmian ewolucyjnych.

Umiejscowienie powyższych treści i wymagań $\mathrm{w}$ podstawie programowej zgodnie $z$ art. 4 ust. 24 ustawy - Prawo oświatowe oznacza, że są one obowiązkowymi treściami nauczania, które uczeń powinien znać po zakończeniu określonego etapu edukacyjnego. Na nauczycielu spoczywa obowiązek wyłożenia materii przewidzianej w podstawie programowej oraz oceny jej znajomości przez ucznia. Obecność teorii ewolucji, podobnie jak i innych treści w podstawie programowej, wpisuje się w dyrektywę, zgodnie z którą szkoła ma obowiązek zadbać o wszechstronny rozwój każdego ucznia, jak wprost stanowi załącznik 4 do rozporządzenia w sprawie podstawy programowej dla szkół podstawowych.

Niezależnie od powyższego, w niniejszej opinii warto przytoczyć stanowisko Kościoła katolickiego wobec teorii ewolucji. Papież Pius XII w encyklice Humani generis z 1950 r., uwzględniając stan badań naukowych swojej epoki, a zarazem wymogi stawiane przez teologię, uznawał doktrynę ewolucjonizmu za poważną hipotezę, godną rozważenia i pogłębionej refleksji. Papież Pius XII sformułował przy tym dwa warunki: nie należy przyjmować ewolucjonizmu w taki sposób, jak gdyby była to już nauka pewna oraz jak gdyby można było abstrahować od tego, co o początkach świata i człowieka mówi Objawienie ${ }^{6}$.

Jan Paweł II w wystąpieniu Orędzie życia. Przestanie Ojca Świętego do członków Papieskiej Akademii Nauk z 22 października 1996 r. odniósł się do encykliki papieża Piusa XII twierdząc, że: Encyklika Humani generis traktowała naukę o ewolucjonizmie jako poważna hipotezę, tak samo godna rozpatrywania i badania jak jej przeciwna hipoteza. Dzisiaj, prawie pót wieku po opublikowaniu tej encykliki, nowe osiagnięcia doprowadziły do uznania, iż teoria ewolucji jest więcej niż hipoteza. Rzeczywiście godnym uwagi jest, że teoria ta jest przez badaczy coraz więcej akceptowana $z$ powodu wielu odkryć w różnych dziedzinach nauki. Zgodność niezależnych od siebie wyników prac (ani wymyślona, ani fabrykowana) jest już sama znaczacym argumentem dla tej teorii (pkt 4$)^{7}$.

Rozważania nad podglądem Kościoła katolickiego w stosunku do teorii ewolucji podsumowuje papież Franciszek, który w Przemówieniu do członków Papieskiej Akademii Nauk z okazji odsłonięcia popiersia Benedykta XVI w dniu 27 października 2014 r. stwierdził, że: Big-Bang [Wielki wybuch], który dziś sytuuje się u poczatku świata, nie przeczy boskiemu działaniu stwórczemu, lecz go wymaga.

6 W stanowisku Rady Naukowej Konferencji Episkopatu Polski z 27 listopada 2006 r. „Kościół wobec ewolucji” przywołuje się m.in. twierdzenie papieża Piusa XII w sprawie doktryny ewolucjonizmu.

7 Jan Paweł II, Orędzie życia. Przesłanie Ojca Świętego do członków Papieskiej Akademii Nauk (22 października 1996 r.), „W Drodze” 1997, nr 9, pkt 4. 
Ewolucja natury nie jest sprzeczna z pojęciem stworzenia, ponieważ ewolucja zakłada stworzenie bytów, które ewoluują ${ }^{8}$.

\section{Wnioski}

Realizacja propozycji usunięcia z treści preambuły do Prawa oświatowego sformułowania „respektując chrześcijański system wartości” wysuwana w petycji mieści się w zakresie swobody decyzyjnej ustawodawcy. Jednakże w ocenie autora niniejszej opinii przytoczona w petycji argumentacja mająca tłumaczyć podjęcie działań w celu usunięcia tego zapisu, nie jest w pełni przekonująca. Różnorodność treści nauczania obecna w podstawie programowej, nie jest wyrazem pogwałcenia czy braku respektowania wartości, do których odwołuje się preambuła. Przeciwnie, pozwala ona spełnić podstawowy cel szkoły, jakim jest troska o wszechstronny rozwój każdego ucznia.

\section{Bibliografia}

Konarzewski K., Reforma oświaty. Podstawa programowa i warunki kształcenia, Warszawa 2004.

Król A., Kuzior P., Łyszczarz M., Prawo oświatowe. Komentarz do ustawy o systemie oświaty, Warszawa-Bielsko-Biała 2011.

Morawski L., Zasady wykładni prawa, Toruń 2010.

Pilich M., Ustawa o systemie oświaty. Komentarz, 2015, LEX.

8 Https://opoka.org.pl/biblioteka/W/WP/franciszek_i/przemowienia/ewolucja_27102014.html [dostęp 30 maja 2019 r.]. 